\title{
Krize sousedství? Narušení prostorovosti kultury argentinského zahradního města Lomas del Palomar Tereza Hodúlová
}

DOI: 10.21104/CL.2021.4.02

\author{
Neighbourhood Crisis? The Disruption of the Spatialized Culture \\ of the Argentinian Garden City of Lomas del Palomar
}

\begin{abstract}
The Argentinian garden city of Lomas del Palomar was formerly, socially and spatially, a very specific neighbourhood in Argentina. It was designed by the German architect Zeyen and was built on a human scale with a selfcontained community. Recently, it has been undergoing a material and inner transformation. Elements such as high fences, security cameras and multi-storey buildings that do not respect the original character of the place have had an impact on the residents' attachment to the place of their home. Employing Setha Low's theoretical approach of spatialized culture (2017), the aim of this paper is to show how the residents of Ciudad Jardín Lomas del Palomar are attached to the place of their home and neighbourhood and how this attachment is reconceptualized through the current socio-spatial changes of the place. Based on ethnographic research, this paper seeks to explore how these changes affect the spatialized culture of a place through the residents' everyday perception, understanding and experience of the place.
\end{abstract}

\section{Key words}

garden city, place, place attachment, space, spatialized culture

\section{Contact}

Mgr. Tereza Hodúlová, Fakulta humanitních studí́, Univerzita Karlova, Pátkova 2137/5, 18200 Praha 8 - Libeň, Czech Republic; e-mail: tereza. hodulova@seznam.cz.

\section{Jak citovat / How to cite}

Hodúlová, Tereza. 2021. Krize sousedství? Narušení prostorovosti kultury argentinského zahradního města Lomas del Palomar. Českýlid 108, 431-453. https://doi.org/10.21104/CL.2021.4.02 


\section{Úvod}

Zahradní město. Místo, které v očích svých tvůrců představovalo ideální domov, zdravé a kvalitní bydlení pro všechny, jenž svou materiální podobou dokáže elimininovat sociální konflikty a pozdvihovat člověka $\mathrm{k}$ lepšímu. Co se stane s významem takového místa, vstoupí-li do něj nové sociálně-prostorové prvky, jako je diskontinuita, nerovnost či bariéra, nerespektující jeho původní charakter?

Zahradní město Lomas del Palomar se nachází dvacet kilometrů od Buenos Aires v oblasti Tres de Febrero. Bylo postaveno v letech 1942-1944 a je považováno za první sídelní celek v Argentině, který ctí principy Howardovy teorie zahradního města (Howard 1946). V návaznosti na Ebenezera Howarda architekt města Lomas del Palomar Erich Zeyen věnoval při plánování zvláštní pozornost sociálnímu aspektu zahradního města. Výzkum archivních pramenů, zejména časopisu stavebního družstva F.I.N.C.A a Zeyenova deníku, ukázal, že Zeyen chtěl vytvořit místo, které by vyhovovalo jak potřebám lokálních obyvatel, tak potřebám přistěhovalců. Místo, které by respektovalo ekonomické i sociální postavení jedince, jeho rasu i kulturu. Prostorové uspořádání zahradního města slučující výhody města a vesnice mu mělo posloužit jako nástroj k eliminaci společenských konfliktů. $\mathrm{V}$ dnešní době, téměř osmdesát let od svého vzniku, je Lomas del Palomar v architektonické a urbanistické obci stále př́kladem vhodné zástavby, která respektuje principy udržitelnosti s ohledem na lidský rozměr architektury (Jagemann 2016). Přesto bylo v posledních letech na Lomas del Palomar upozorňováno zejména v souvislosti se sousedskou komunitou, která aktivně bojuje za jeho zachování a za obnovu jeho poškozených částí. $\mathrm{Z}$ toho důvodu se zahradní město jevilo jako vhodný výzkumný terén pro zkoumání vztahu mezi prostorovou, sociální a významovou povahou místa. Ačkoliv existuje několik architektonických i urbanistických studií (Gallanter 2012; Jagemann 2016), které se věnují zahradnímu městu Lomas del Palomar, z etnografického hlediska se jedná o stále neprobádanou lokalitu.

Cíl etnografického výzkumu v Lomas del Palomar byl vícevrstevnatý. Záměrem bylo zjistit, jak se materiální změny prostoru města promítají do jeho sociálního prostoru, jak rezidenti skrze tyto změny místo svého domova prožívají a jaké významy mu přikládají. Dále rozpracovat koncept narušení prostorovosti kultury a tím přispět k pojetí prostorovosti kultury Sethy Low (2017).

Zajímalo mě, jakou roli hrají fyzické prvky nerespektující původní charakter zahradního města Lomas del Palomar, jako jsou v posledních letech budované několikapatrové budovy, vysoké ploty, bezpečnostní prvky ve veřejném prostoru, $\mathrm{v}$ re/konceptualizaci vztahu rezidentů k místu jejich domova. Jako teoretické východisko jsem zvolila koncept 
prostorovosti kultury ${ }^{1}$ antropoložky Sethy Low (2017), který je fúzí sociální produkce prostoru a sociální konstrukce prostoru, přičemž klade explicitní důraz na jedince a jeho tělesně prožívaný a produkovaný prostor (embodied space). Prostorovost kultury spojuje sociální, ekonomické, ideologické, technologické aspekty materiálního nastavení prostoru spolu se symbolikou, zkušeností a významem místa. Významy místu přikládá jedinec na základě vzpomínek, emocí, zkušeností nebo zprostředkovaných sociálních procesů, jako je změna, konflikt nebo kontrola (Low 2017: 7). Skrze významy, které jedinec místu přikládá, konstruuje širší chápání toho, kým je, a přináležitostí k místu posiluje svou vlastní identitu, at' už jako jednotlivce, nebo člena komunity (Manzo 2020). Narušení či změna vazby k místu může tuto identitu ovlivnit (Brown - Perkins 1992: 280).

S použitím konceptu prostorovosti kultury, který umožňuje studovat místo s důrazem na vnější materiální dimenzi domu i na vnitřní významy, které domovu jedinec přikládá, se snažím postihnout prostorovost kultury zahradního města Lomas del Palomar. Na prŕkladu etnografické studie ulice Las Tipas ukazuji, co mohou způsobit nové, cizí prvky a významy jim přikládané, které narušují původní prostorovost kultury místa. Explicitní důraz přitom kladu na proces narušení prostorovosti kultury a její možnou rekonceptualizaci právě skrze tyto významy, a tím rozšiřuji pojetí Sethy Low. Tento př́íspěvek je rovněž předkládán se záměrem rozšiŕít dosavadní kvalitativně založené bádání o současném městěe místě a domovu.

\section{Etnografie místa a prostorovost kultury}

V koncepčním vztahu prostor-místo je prostor obecnějším, abstraktním konstruktem, materiálním základem. Prostor je sociálně produkován jedincem i skupinami, stejně jako historickými nebo politickými silami (Lefebvre 1991; Harvey 1973). Teprve skrze významy, které prostoru jedinec přikládá, přetvář́ prostor na místo (Hirsch 1995; Mácha 2010: 232).

Etnografický, tělesně prožívaný a produkovaný prostor, tak jak ho chápe Low (2017: 94), zahrnuje obojí, materiální a významový pohled. Prostorovost kultury spojuje sociální, ekonomické, ideologické, technologické aspekty materiálního nastavení prostoru se symbolikou, zkušeností a významem místa zprostředkovaných sociálními procesy, jako je změna, konflikt nebo kontrola (Low 2017: 7). Spojuje sociální produkci prostoru (Harvey 1973; Lefebvre 1991), která odkazuje na jeho hmotné aspekty, odkrývá historické motivy a souvislosti plánování a rozvoje, a sociální konstrukci

1 Spatialized culture (zprostorování kultury) charakterizuje vztah prostoru a kultury. V tomto článku užívám termín prostorovost kultury. 
prostoru (Berger a Luckmann 1967), která se soustředí na pojetí prostoru skrze vzpomínky, pocity, představy, které se propouštějí do míst a vyjadřují konkrétní významy a symboliku. Tuto dualitu sociální konstrukce a produkce prostoru Low ještě více přibližuje antropologii, když ji rozšiřuje o takzvaný embodied space, ${ }^{2}$ tedy prostor, který je tělesně prožívaný a zároveň tělesně produkovaný. Podle Low (2003: 39) prostorové analýzy často zanedbávají „lidské tělo“, jedince, a to z důvodu komplikovaného rozlišení jeho subjektivního (psychického a sociálního) a vnějšího (biologického a hmotného) aspektu. Pojem embodiment respektuje důležitost těla jako fyzické a biologické entity a zároveň jako prožité, žité a kulturní zkušenosti. Jedinec představuje časoprostorovou jednotku plnou pocitů, myšlenek, preferencí a záměrů, zároveň i jednotku kulturní. Jedinec je tím, kdo má potenciál pro vytváření sociálních vztahů, vazeb, každodenních rutin a významů, kterými nakonec mění prostor v místo, proto musí být znovu a explicitně zohledněn. Implikace embodied space do studia místa slouží např́íklad k porozumění prostorové orientaci, pohybu nebo akci, jako je forma protestu nebo rituálu, ve které lidská zkušenost a podvědomí nabývá hmotné a prostorové podoby (Low 2017: 95).

Jako další teoretický rámec byl v této studii využit koncept place attachment ${ }^{3}$ - přináležení $\mathrm{k}$ místu. Koncept byl původně vymezen environmentálními psychology, kteří pomocí něj zkoumali vztah mezi člověkem a jeho materiálním prostředím a identitu místa (Prohanski 1978). Užití konceptu se v posledních letech rozšírilo i do oblasti urbánní antropologie (Altman - Low 1992; Manzo 2020), ve které je place attachment vhodným konceptuálním rámcem ke studiu identity, kolektivní paměti, migrace, moci a jiné. Odkazuje totiž na emocionální a afektivní vztah jedince k prostoru, na představy, zkušenost a symbolický význam prostoru. V tomto článku tedy koncept přináležení $\mathrm{k}$ místu vysvětluje zpưsob, jakým se člověk váže k prostředí svého domova, který spočívá v prožívání domova a péči o něj. Přičemž domov je vnímán jako komplexní, mnohovrstevnatý terén (Gibas 2017), který je konstruován na základě sdílení osobní zkušenosti i prostoru s dalšími lidmi, je místem přináležení $\mathrm{k}$ celku či kolektivitě, ale zároveň místem rozporů, tlaků i rezistence (Galčanová 2014).

Studie se odehrává v zahradním městě Lomas del Palomar a pro její zarámování následuje část o proměnách koncepce zahradních měst.

2 Vzhledem k významové nepřesnosti doslovného překladu je v textu používán anglický pojem embodied space nebo jeho významový opis tělesně prožívaný a produkovaný prostor.

3 Koncept place attachment je v českých studiích překládán různě (vazba k místu, přináležení $\mathrm{k}$ místu, připoutání $\mathrm{k}$ místu). V tomto článku bude užíván př̀klad přináležení k místu. 


\title{
Zahradní město dříve a dnes
}

V důsledku probíhajících společenských a hospodářských změn na přelomu 19. a 20. století docházelo k zintenzivnění procesu urbanizace. Nekontrolovatelné rozrůstání měst a jejich průmyslové zástavby bez jakéhokoliv urbanistického plánu způsobilo rozšiřování periferií, kolonií a neorganizovaně mísících se prvků. Ve městech byl nedostatek bytových jednotek a veřejného prostoru, zhoršila se kvalita bydlení, hygienické podmínky i ovzduší (Horská - Maur - Musil 2002: 280). Teorie zahradního města formulovaná Ebenezerem Howardem se stala jednou z nejvýznamnějších urbanistických koncepcí 19. století. V reakci na neutěšené podmínky Londýna 19. století a inspirován myšlenkami hnutí Arts and Crafts ${ }^{4}$ představil teorii zahradního města centrického typu. Jeho teorie obhajovala sídelní strukturu cenově dostupných rodinných domů umístěných v zeleni, která by vyvážila industriální podobu tehdejších průmyslových měst a zhoršující se kvalitu života v nich. Principem zahradních měst mělo být sloučení benefitů města $\mathrm{s}$ výhodami vesnického prostředí. Zahradní město mělo představovat kompromis, který respektoval tyto zásady:

\begin{abstract}
„Lid: kam pưjde? Město-venkov: Krása prírody. Společenská př́ležitost. Pole a sady snadno prístupné. Nizké nájemné, vysoké mzdy. Nízké daně, dostatek práce. Nizké ceny, žádná úporná práce. Možnost podnikání, př́liv kapitálu. Čistý vzduch a voda, dobréodvodňování. Krásné domy a zahrady, žádný kouř. Svoboda. Sociální soulad."
\end{abstract} (Howard 1956: 18)

Cílem Howarda bylo vytvořit pružný model města, který lze realizovat i za předpokladu implementace národních, tradičních i osobních aspektů dané kultury. Chtěl vybudovat zdravé a kvalitní bydlení pro všechny. Obhajoval myšlenky sociální spravedlnosti a chtěl vytvořit takové bydlení, které svou materiální podobou eliminuje sociální konflikty. Jeho rekonstrukce měst neměla vyřešit jen urbanistickou krizi, ale také krizi sociální. Nešlo tedy jen o inovativní urbanistické řešení, ale o to najít pro dělníky v průmyslu lépe placenou práci, zajistit zdravější prostředí jejich domovi̊ a zvýšit jejich zdravotní standard (Vacková 2010: 151). Howard věřil, že sociální solidarita se ve společnosti rozvíjí jen tehdy, pokud vedle sebe žije ten, kdo byl dříve segregován, at' už z důvodu společenské třídy, nebo rasy.

4 Arts and Crafts bylo reformátorské hnutí, které prosazovalo kvality řemeslné výroby a odkazovalo na tvůrce. Z hnutí vycházela i architektura, která obhajovala tradiční pojetí rodinného domu a venkovských anglických sídel. 
Ačkoliv se hnutí zahradních měst šírilo do celého světa, mělo i své kritiky. ${ }^{5}$ Ti upozorňovali na neefektivní propojení s dosavadním urbanizovaným územím. Přesto, že Howard nebyl příznivcem vzniku předměstí, v některých př́padech vznikaly za hranicemi měst namísto soběstačných celků nové monofunkční residenční oblasti, dnešní suburbia, která spíše, než aby byla samostatným celkem, podporovala centrum města. Tomu pomohl i technický pokrok a postupný rozvoj transportního systému. Jiná kritika zahradních měst se dotýká jejich prŕlišné exkluzivity. Takové projekty nejčastěji nalezneme ve střední a jižní Americe ve formě luxusních zelených předměstí nebo gated communities. Př́íkladem je zahradní město América v Sao Paolu navržené architekty Unwinem a Parkerem nebo zahradní město Chapultepec a Colonia Hipodromo de la Condesa v Mexiku (Devereux 2015). Tato města sice aplikují urbanistický model kruhových a radiálních tř́d lemovaných zelení, nedodržují ale sociální model, který byl nedílnou součástí Howardovy teorie zahradních měst (Almandoz 2004).

\section{O výzkumu}

Výzkum prostorovosti kultury zahradního města Lomas del Palomar měl tři sféry: zúčastněné i nezúčastněné pozorování sledující užívání prostoru; interview s rezidenty zaměřené na prostorové změny, významné prvky města, události, vzpomínky spojené s prostorem, doplněné expertním interview s architektem Hernánem Jagenmannem; a analýzu archivních pramenů soustř̌eděnou na okolnosti vzniku a původní obraz města (časopisů, které v letech 1942-1946 vydávalo stavební družstvo F.I.N.C.A, a deníku Ericha Zeyena, jehož kopie je dostupná v místní knihovně).

S použitím metody sněhové koule jsem realizovala osm formálních polostrukturovaných rozhovorů s rezidenty: ${ }^{6}$ čtyři z nich byli starousedlíci (děti prvních obyvatel: Ali, Facu, Anita, Emily), dva informátoři zastupovali střední generaci (vnoučata prvních obyvatel: Sol, Gui), dva informátoři zastupovali nejmladší generaci (pravnoučata prvních obyvatel: Ruth,

5 První zahradní město, které bylo realizováno dle Howardova plánu bylo Letchworth, vybudované dle návrhu britských architektů Parkera a Unwina. V Německu na něj navázal architekt Ernst May ve svém projektu města Römerstadt, ve Finsku architekt Heikki von Hertzen se svým zahradním městem Tapiola, které je dodnes považováno za jeden z nejfunkčnějších realizovaných projektů zahradních měst vůbec. Nejzdařilejšími realizacemi zahradních čtvrtí v Čechách jsou čtvrti Spořilov a Hanspaulka.

6 Přes několik pokusů se mi nepodařilo uskutečnit rozhovor s nově přistěhovalými rezidenty, kteří bydlí ve zrekonstruovaných domech v ulici Las Tipas. 
Mari). ${ }^{7}$ Polo-strukturované rozhovory probíhaly vždy v zahradním městě, bud' u informátorů doma, nebo v oblíbené místní kavárně Café Martinéz na hlavním náměstí. Koncepce rozhovorů se dotýkala prostorových aspektů zahradního města, jeho proměn, významných událostí, kolektivní paměti, materiálních i symbolických forem pojetí prostoru. Polostrukturované rozhovory jsem doplnila o expertní rozhovor s architektem Hernánem Jagemannem, který již několik let upozorňuje na architektonické a urbanistické hodnoty zahradního města a podílel se na vytváření architektonických studií týkajících se citlivé revitalizace jednotlivých částí. Hernán sice není rezidentem zahradního města, ale jeho častým návštěvníkem, jelikož má mezi rezidenty mnoho přátel. Poskytl mi také urbanistickou dokumentaci jako mapy, územní plány, architektonické návrhy a postupy jejich realizací. Vzhledem k tomu, že ne všichni informátoři ovládali anglický jazyk (zejména starousedlíci) a moje španělština nebyla na takové úrovni, abych se s jistotou vyhnula př́padnému neporozumění, součástí všech rozhovorů byla Mari, ${ }^{8}$ která se stala mou gatekeeperkou. S některými informátory jsem se setkala opakovaně a provedla jsem s nimi další neformální rozhovory, které se většinou týkaly postupu mého výzkumu a mého zabydlování v Argentině. I ty ale hrály v mém výzkumu důležitou roli, jelikož mě s informátory sbližovaly a pomohly mi pochopit podstatné sociokulturní souvislosti.

Výzkum archivních pramenů byl založen zejména na studiu dobového časopisu F.I.N.C.A, který vydávalo od roku 1942 Stavební družstvo zahradního města Palomar F.I.N.C.A jako průvodce stavbou a prvními lety života v zahradním městě Palomar. Časopisy jsem našla archivované v místní knihovně Biblioteca Popular Ciudad Jardín, bohužel se nezachovala všechna čísla. Družstvo vydávalo časopis nejprve čtvrtletně a informovalo v něm

7 Z důvodu zachování anonymity byla jména informátorů změněna. Číslo za jménem informátora odkazuje na generaci, do které spadá: 1. děti prvních obyvatel, 2. vnoučata prvních obyvatel, 3. pravnoučata prvních obyvatel. Přepisy rozhovorů jsou uloženy v osobním archivu autorky.

8 Mari je studentka sociologie a jedna z provozovatelek Muzea La Montaña, které se svou sestrou spravuje několik let. Do muzea jsem se vydala v rámci prvních dnů terénního výzkumu zahradního města. Propojení s Mari bylo pro můj výzkum zcela zásadní. Se svou sestrou se zahradním městem, které je jejich domovem, intenzivně zabývají. Shromaždují dokumenty jako staré fotografie, pohlednice, obrazy s motivem zahradního města, zajímají se o Zeyena a historii vzniku města a aktivně se podílejí na mnoha kulturních akcích, které pod záštitou muzea pořádají (sousedská setkání, oslava narozenin zakladatele Zeyena, oslava dne urbanismu, salsa večery). Mari, která spadá do „generace pravnoučat starousedlíků “, byla napojená na sousedskou komunitu, a jelikož uměla výborně anglicky, účastnila se rozhovorů s rezidenty a pomáhala mi s překladem. 
o procesu výstavby, později F.I.N.C.A vycházel jako měsíčník. Běžné číslo popisovalo aktuální dění ve městě, informovalo o novinkách, o kulturních a sportovních akcích (pravidelně byl zveřejněn program místního kina Helios a rozpis místních fotbalových zápasů). Dále časopis poskytoval prostor pro reklamu místních obchodů, čímž podporoval jejich rozvoj. Kromě toho značnou část časopisu vytvářeli sami obyvatelé zahradního města, kteří v časopise publikovali např́íklad fotografie svých domů a svépomocně upravených interiérů či zahrad, čímž se vzájemně inspirovali. Poslední stránky časopisu byly vždy věnovány oslavencům z řad rezidentů nebo novorozencům, kteří byli touto formou přivítáni jako noví členové města. Dalším podstatným zdrojem byl deník architekta Zeyena Así la levantamos, ${ }^{9}$ do kterého od roku 1933 zaznamenával všechny podstatné události týkající se jak projektu zahradního města, tak jeho realizace, stejně tak jako neuskutečněné vize a překážky, které projekt potkaly. Deník byl pro mě jedinečnou př́ležitostí poznat Zeyena jako architekta, zapáleného tvůrce, ale také jako člověka, který dokázal spojit velkou motivaci s ještě větší energií, aby mohl plnit své sny.

Ačkoliv jsem se během pozorování snažila zachytit nejrůznější socioprostorové procesy v místě probíhající, svou pozornost jsem soustředovala především na to, jak je prostor tělesně prožíván, produkován a vyjednáván skrze lidské tělo, každodenní praktiky, rituály a pohyb. Během pěti měsíců jsem město nesčetněkrát procházela, zapisovala jsem své dojmy i vjemy z prostorového uspořádání a užívání prostoru do terénního deníku. Metodu zúčastněného pozorování jsem aplikovala při neformálních rozhovorech s ostatními rezidenty nebo kolemjdoucími a zejména na sousedské oslavě $\mathrm{v}$ rámci Dne urbanismu, která byla pořádána aktivními členy sousedské komunity pod záštitou Muzea La Montaňa 3. prosince 2018.

Výzkum zahradního města jsem prováděla v období od záŕí 2018 do ledna 2019. Zprvu jsem do Lomas del Palomar dojížděla z Buenos Aires, poslední měsíc jsem strávila intenzivním pobytem v místě svého výzkumu. Následující text sumarizuje archivní část výzkumu, který se zaměřoval na okolnosti vzniku zahradního města Lomas del Palomar.

\section{Vybudování Lomas del Palomar}

Argentinské zahradní město Lomas del Palomar vzniklo jako první, a ve své velikosti a propracovanosti i jediné zahradní město v Argentině

9 Kopii deníku psanou ve španělštině mi pomohla sehnat v místní knihovně Mari, která jej následně oskenovala a digitalizovala, větší část přeložila do angličtiny. 

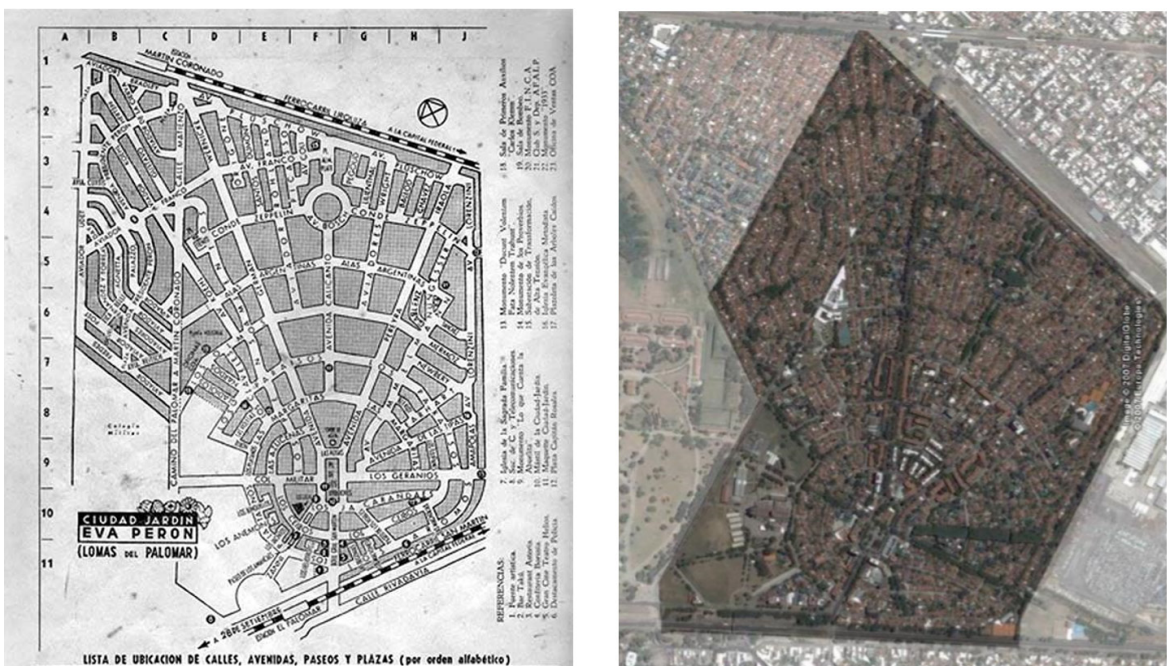

Obr. 1 Mapa zahradního města Lomas del Palomar. Zdroj: Jagemann, 2016.

(obr. 1). ${ }^{10}$ Masivní urbanizace probíhala v Argentině během 20. a 30. let 20. století. Města byla přeplněná a vyšší a střední třída obyvatelstva začala hledat nové rezidenční lokality, čímž určovala směr expanze hlavních měst. ${ }^{11}$ Rozvíjel se moderní dopravní systém se třemi režimy připojení (trolejbusy, autobusy a železnice), který vydláždil cestu k rozšŕření města za hranici federálního okresu, a předměstí Buenos Aires se začalo dramaticky rozrůstat. ${ }^{12}$

10 V době výstavby Lomas del Palomar byl prezidentem liberál Hipolito Yrigoyen, který prijal několik sociálních a ekonomických reforem na pomoc malým podnikatelům a farmářským rodinám, kteři se ocitli v nouzi v důsledku velké hospodářské krize. Následovalo více než desetiletí pod vládou Juana Dominga Perona, jehož vlastní politika peronismu usilovala o sociální zabezpečení a blahobyt, ale také o zajištění dominantního postavení Argentiny v Jižní Americe. Politika peronismu se projevovala rozsáhlým znárodňováním, podporou odborů a snahou o zlepšení sociálního postavení nejchudších obyvatel a dělníků. V době peronismu se Argentina zadlužila a ocitla v hluboké politické a hospodářské krizi.

$11 \mathrm{Z}$ důvodu nově přicházejících imigrantů došlo v Buenos Aires mezi dvacátými a třicátými lety 20. století k masivnímu nárůstu obyvatel z 1693000 na 2287000 (Sargent 1974).

12 Rezidenční celky s nízkou zástavbou rodinných domů se stavěly především během prezidentské vlády Juana Dominga Peróna (40. až 50. léta 20. století). Ideologické pozadí perónismu se promítlo do architektonického a urbanistického rázu sídliště Cornelio Saavedra v Buenos Aires (1949) nebo sídliště Evita v Corrientes (1950/51). Součástí těchto celků nebyla občanská vybavenost, a proto nebyly stavěny jako soběstačné. Dalším rozdílem je, že poskytovaly bydlení vyšší sociální třídě obyvatel, a tím, že byly explicitně exkluzivní, vytvářely hranici s vnitřním městem. 
Architekt Zeyen, který do Argentiny emigroval v roce 1929, měl na poměry urbánního prostoru Jižní Ameriky neobvyklý cíl. Chtěl vytvořit malé město, které by vyhovovalo jednak potřebám místních obyvatel, ale také potřebám přistěhovalců, jako byl on sám. Místo, kde lidé žijí v souladu se sebou samými a v souladu s prŕrodou, místo, které znal z urbanizované Evropy - zahradní město. Trvalo třináct let, než argentinská vláda schválila jeho projekt. Úředníci nevěřili, že se projekt někdy realizuje, a říkali mu „Villa Illusion“, jak se píše v Zeyenově deníku. Největší překážkou bylo pro Zeyena najít vhodný terén, který by vyhovoval jeho vizím. Jak zmínil ve svém deníku:
„Fednoho odpoledne jsem navrhl, že bychom neměli naši pozornost soustředit jen na sever. Západ byl také zajímavý a cítil jsem, že je tu něco zuláštního. ,Ó můj bože! Co budeme dèlat na západě? Nic tam není. Nikdo tam nebude chtít žit, ' odpověděl prítel. Následujicího dne jsem se vydal na západ. Přešel jsem přes Avenue General Paz, přes Caseros a najednou jsem byl ohromen. Přede mnou, zalitý sluncem, budoucí Ciudad Jardín v Lomas del Palomar. "(Zeyen 1933: 2)

Zeyen popsal tento prostor jako „něco, co v Argentině nikdy neviděl“. Věděl, že avenue pojmenovaná Richmondský park, plná vzrostlých stromů eukalyptu, bude vstupní branou zahradního města. V roce 1942 už konečně mohl začít stavět. Založil stavební firmu F.I.N.C.A (Financeria Inmobiliara, Nacional Construcciones y Anexox), která zastřešovala vše od budování a financování projektu, po poskytování bezúročných úvěrů jednotlivým rezidentům. ${ }^{13}$ Družstvo F.I.N.C.A také pravidelně vydávalo vlastní časopis (obr. 2).

„Kde stojí úspěch zahradního města? Odpověd'je jednoduchá. Úspě-
chem jsou muži z F.I.N.C.A, kteř́ dali sto procent své síly tomuto
městu. Usínali i vstávali s vírou ve město Lomas del Palomar."
(Zeyen 1933: 102)

Na předběžném projektu se vedle Zeyena podíleli i němečtí architekti Federico Behrendt a Juan Behrendt spolu s argentinským architektem Oscarem Mongsfeldem. Zahradní město bylo tvořeno různými typy rodinných domů, většinu z nich tvořily rodinné domy německého stylu se střechou s výraznými červenými taškami a s neoplocenou předzahrádkou (obr. 3).

13 Stavební spořitelny, které v Argentině fungovaly od roku 1935, byly složeny ze dvou typů partnerů: těch, kteří provedli vklady, a hypotečních investorů. Spořitelny mohly fungovat pouze na základě poskytování úvěrů na bydlení formou podpory úspor na koupi domu. 
Dalším typem rezidenční zástavby byly čtyřpatrové bytové domy, které hraničily s každým komerčním náměstím. Většinu půdy ale zabíraly právě rodinné domky. Samotné bydlení bylo navrženo s nízkými stavebními i pořizovacími náklady na úkor obytného prostoru ve prospěch otevřeného zeleného prostoru zahrad. Zeyen stavěl město jako soběstačné, už součástí plánů tedy byly veřejné instituce, jako jsou nemocnice, hasičská základna, škola, divadlo, kino a komerční služby jako obchody a restaurace (F.I.N.C.A Magazine 1947). Rekreační funkci prostoru podpořil hlavní veřejný park Plaza del Avion a mnoho menších parků a menších náměstí lemujících jednotlivé čtvrtě. Vše bylo uspořádáno podle diagramu Howardova zahradního města. Př́roda byla pro Zeyena zdrojem zdravého života, morálky a krásy, prohlubovala lidskou vnímavost a ducha obyvatel pozvedla k vyšší, mírumilovnější a racionálnější rovině (Zeyen 1933: 40). Všechny ulice byly hustě lemovány vzrostlými stromy a po stromech rovněž pojmenovány. Zeyen nechtěl stavět jen jednotlivé domy se zahradami, ale propojené sousedské čtvrtě. Při plánování proto věnoval zvláštní pozornost sociálnímu aspektu zahradního města. Chtěl vytvořit spíše čtvrt' než město. Místo, kde se sousedé nejen zdraví, ale také znají. Druhým jeho cílem, který často zmiňuje ve svých zápiscích, bylo vytvořit město pro všechny - pro dělníka i vedoucího pracovníka, malého obchodníka i milionáře, pro křestana i ateistu, pro Evropana i Argentince (Zeyen 1933: 80). Nástrojem k eliminaci ekonomických, rasových, sociálních a kulturních rozdílů mu byl prostor. Obytné domy stejného typu, podobné velikosti se stejnou zahradou, kostely různých náboženství, otevřené prostory jako místa setkávání. Přál si, aby bylo zahradní město Lomas del Palomar krásným domovem, trochou země, rodinou a blízkou komunitou pro všechny.

\section{„Když řeknu, že žiju v zahradním městě Lomas del Palomar, neř́kám tím, že jsem bohatý nebo chudý. Říkám tím, že se mi žije dobře a že tu mám krásný domov. A to je to, na co mohou být obyvatelé města hrdí." (Zeyen 1933: 92)}

Prvními obyvateli města byli většinou příslušníci střední tř́idy - obchodníci, ale i dělníci společnosti F.I.N.C.A. Ta poskytla svým zaměstnancům výhodné úvěry; v praxi to vypadalo tak, že si budoucí rezidenti postavili svůj dům vlastními silami. Domy byly tedy od začátku v osobním vlastnictví. Část obyvatel tvořila skupina západoevropských imigrantů, většinou z Německa, Itálie, ale také ze Švýcarska, Belgie nebo Chorvatska, část Argentinci (F.I.N.C.A Magazine 1949). Jedné části města se lidově ř́kalo „malá Itálie“ (la pequeňa Italia). V roce 1955 už ve městě žilo 12601 obyva- 

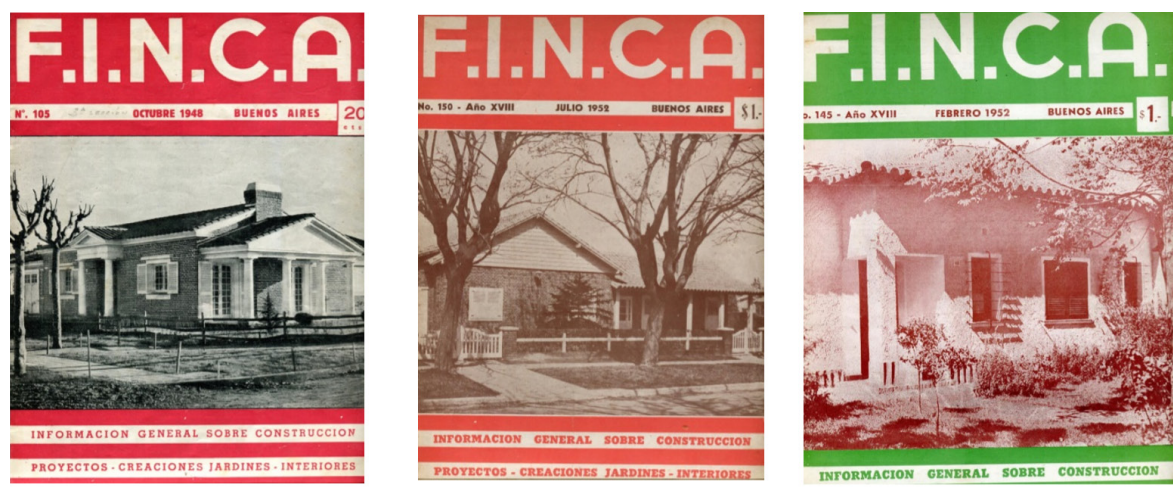

Obr. 2 Časopis stavebního družstva F.I.N.C.A

tel, z čehož $66 \%$ tvořily rodiny zaměstnanců F.I.N.C.A a $13 \%$ obchodníci. ${ }^{14}$ Komunita, která se $\mathrm{v}$ jednotlivých čtvrtích mezi sousedy utvořila, byla během prvních desetiletí uzavřená a homogenní (Gallanter 2012). Téměř každý znal svého souseda, domy zůstávaly během dne otevřené a sousedé se snažili o udržení bezpečné a přátelské atmosféry ve své čtvrti. Sám Zeyen žil v Lomas del Palomar až do roku 1955, než ho Perónův represivní režim donutil emigrovat do Rakouska. V roce 1960 byla společnost F.I.N.C.A zrušena a jakékoliv další stavební úpravy či rozšiřování města podléhaly pouze správě městské části Palomar.

\section{Narušení prostorovosti kultury Lomas del Palomar}

Teorie zahradního města jako jiné urbanistické koncepce z období 19. a 20. století v sobě nese silný sociální nádech. Snaží se o eliminaci všech dosavadních nevýhod života ve městě a akcentuje výhody života na vesnici. Jak ale takový leitmotiv sociální spravedlnosti dokáže obstát v současném městě, které je odrazem dnešní globalizované kapitalistické společnosti? Se zánikem společnosti F.I.N.C.A v roce 1960 odešel i architektonický a urbanistický „dohled“. Jak říká můj expertní informátor architekt Hernán Jagemann: „Od té chvíle začalo mèsto ztrácet svou urbanistickou logiku." (15. 9. 2018)

Některé domy, obzvláště ty blízko velkého komerčního centra Plaza de los Avidores, začaly být hromadně skupovány, necitlivě přestavovány, nebo dokonce bourány - a s tím se postupně měnila architektonická homogenita

14 Dle posledních dostupných dat z roku 2018 žije v zahradím městě přibližně 18000 obyvatel. 


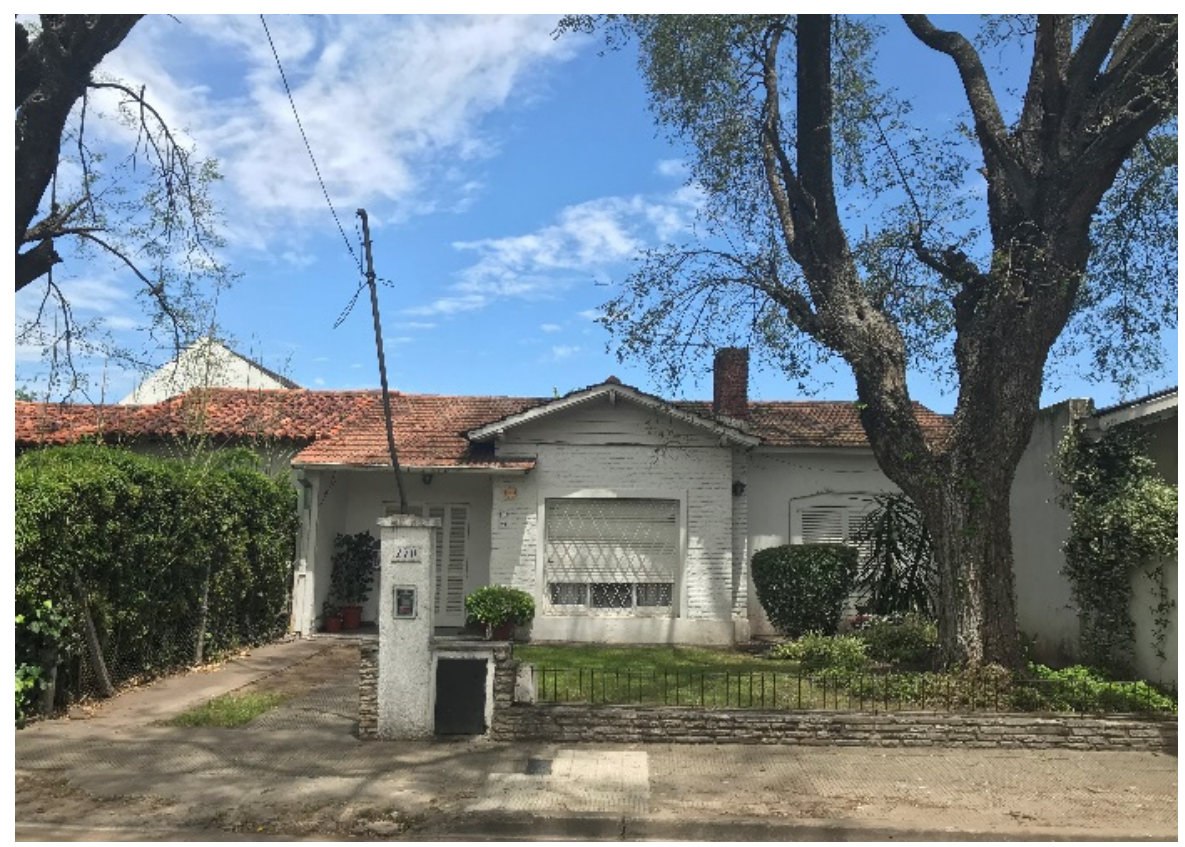

Obr. 3 Původní Zeyenův dům s předzahrádkou a malým plotem. Foto: autorka, 2018.

zahradního města jako celku. V současné době jsou přeměny častější a výraznější. Zásahy jsou nejviditelnější v ulici De las Tipas, ve které nezůstala ani polovina původních domů.

„Celá ta ulice je úplně jiná. Pamatuji si, že to začalo užv 70. letech. Byli to většinou úřredníci, kteři domy od starousedlikio koupili. Anijim za ně moc nezaplatili. Někteř́ dokonce koupili domy dva, oba zbourali a na jejich místè postavili nèco nového, odporného, co připomíná floridskou vilu. Tu potom zase prodali, většinou nějakému umèlci. Do té ulice se začali stěhovat bohatí, dodnes tam dokonce žije několik známých osobností, které vidíme v televizi." (Sol 2, 20. 9. 2018)

„Ulice Las Tipas je část města, která se nejvíce změnila. Myslím si, že v této ulici už nezbývá jediný dům, který by byl pưvodní. Zbourali je a postavili tam domy jako z Miami. To je hrozně smutné. S tím souvisí $i$ to, že je tam tolik kamer a zvýšená ostraha. Ostraha a kamery jsou ted'součástí celého zahradního města, bohužel je to součást Argentiny, od 90. let, co se rapidně zvýšila kriminalita. Ale tahle ulice je extrém. Za chvíli tam nepustí lidi, co bydlí ve vedlejš́ ulici. " (Facu 1, 22. 9. 2018) 
Z mého pozorování: Procházím se ulicí De las Tipas. Je to jedna z ulic, které vedou z prstence komerčního centra. Kdybych neznala plán zahradního města, myslela bych si, že město končí kruhem komerčního centra a z něj vedoucí radiální tř́ídy s obytnými domy už do něj nepatř́i. Jsou sice lemovány stromy, architektonicky jsou ale na první pohled rozdílné. Vedle původního domu dle návrhu Zeyena se tyčí dvoupodlažní, někdy tř́ípodlažní vily, které mají absolutně odlišný architektonický ráz. Působí honosně, někdy až kýčovitě. Málo domů je původních, a pokud tu jsou, jdou těžko rozeznat. Mají barevné fasády a př́istavbu patra nad garáží, střecha je bez klasických červených tašek. V ulici se nenachází jediný dům bez plotu s předzahrádkou. Většina předzahrádek chybí. Domy, které nemají přistavěné patro, jsou schované za vysokými těžkými ploty. Všimnu si zvláštních cedulí s nápisem „zona vigilada amarma comunitaria“" (hlídaná oblast). Těch cedulí vidím víc a uvědomím si, že jsou všude. Postupně vidím i další cizí prvky - ostnaté dráty napnuté nad vysokým železným plotem, skrze který ani není vidět, bezpečnostní kamery (obr. 4). Budka, která z dálky vypadá jako budka telefonní, je „Oficina de seguridad“ s pracovníkem ostrahy. Ještě než se k ní přiblížím, hlídač z ní vybíhá a křičí: "Sin fotografía, sin fotografía,“ ukazujíc na další ceduli s nápisem „sin fotografía“ (žádné focení). Ptá se, co tu hledám, a když zjistí, že se jen procházím, doporučí mi, at jdu do parku.

Vztah k místu svého domova popisovali moji informátoři velice emotivně, často s použitím výrazů, jako je rodina, život, důvěra. Tyto významy byly často explicitně popisovány v souvislosti s fyzickou podobou zahradního města. Zajímavé bylo, že informátoři uvažovali o místě svého domova jako o prostoru celého zahradního města. Hranice domova se tedy vpíjely např́íklad do okolní př́rody, která symbolizovala vzpomínky, tak jak popsala Ruth:

\section{„Mi̊j domov je pohled z okna. Vidím ty stromy, na které se dívala moje babička a dívají se na ně moje děti. Miluju to místo, lidi a př́rodu kolem." (Ruth 3, 4. 10. 2018)}

Zvláštní význam připisovali rezidenti zeleni a př́rodě. Pro Zeyena byla zdrojem dobrého života, morálky, krásy, pro mé informátory byla jednak zárukou spokojeného a zdravého bydlení, zároveň ale neodmyslitelnou součástí jejich domovů, nositelem vzpomínek, emocí. Vzrostlé stromy, parky, všudypř́tomná zeleň a květiny se zkrátka staly symbolem zahradního města a důležitým elementem jeho identity. Zásahy, které jakkoliv eliminovaly přirodní prvky ve městě, vnímali informátoři jako problematické.

„Příroda je nejdůležitější, protože je charakteristikou našeho města, tohoto velmi klidného prostředí. Hodně mě bolí, když vidím, 
kolik zelených zahrádek je nahrazeno smutnými šedými stènami. Kolik trávníkỉ je změnèno na třetí parkovací místo prè domem." (Ali 1, 22. 9. 2018)

Prostorové změny se podle výpovědí mých informátorů promítají do sousedských vztahů, které jsou pro rezidenty zahradního města důležité. Např́klad Guill popsal sousedské vztahy jako něco, co přetrvává, následně ovšem popsal obavu z jejich narušení.

„Mưj otec byljedním z dělniků, kteř́ pracovali pro F.I.N.C.U. Po celou dobu stavby bydleli dèlníci v hotelu, tam se sprátelili. Když si potom vybírali, kde bude stát jejich dům, na který dostali výhodnou pi̊jčku, rovnou věděli, kdo pro ně bude nejlepš̌ soused. Se všemi sousedy jsme dodnes jako rodina. [...] Príistěhovali se sem bohatí. To mi nevadí. My jim to přejeme. Fenže tihle bohatí chtěji, abychom vědèli, že jsou bohatši než my. Staví velké domy a oplocují zahrady, asi abychom jim to nevykradli. Žijí tu už tricet let a my je ani neznáme. Nepozdravíme se. Vlastněje ani nevidíme. Neúčastní se žádné sousedské akce, nepotkáme je v restauraci. "(Guill 2, 4.10. 2018)

Klíčovým indikátorem krize sousedství je strach z kriminality a kriminalita samotná (Taylor 1995). Po hospodářské krizi v roce 2001 se stejně jako v celé zemi i v zahradním městě Lomas del Palomar zvýšila kriminalita. V návaznosti na to vzniklo několik soukromých agentur nabízejících rezidentům bezpečnostní služby. Podle mých informátorů je místo na argentinské poměry bezpečné (alespoň bezpečnější ve srovnání s Buenos Aires a okolními městy). Pocit strachu je naopak umocňován př́tomností prvků, jako jsou mřriže, vysoké železné ploty, kamery. Je důležité zmínit, že bezpečnostní prvky jsou běžnou součástí argentinského městského prostoru. Rezidenční výstavba v Buenos Aires určená pro střední a vyšší tř́́du má často vchody střežené kamerami a vstupy hlídané bezpečnostním personálem. Luxusní rezidenční celky mají výhradně charakter gated communities, rodinné domy v předměstí Buenos Aires jsou obestavěny vysokými betonovými ploty a lemovány ostnatým drátem (Low 2003; Moura 2003). Zahradní město Lomas del Palomar je unikátní právě v tom, že tyto prvky stále nejsou jeho přirozenou součástí a rezidenti je vnímají jako prvky narušující jejich sousedství.

„Samožrejmě je to jejich soukromí, mohou mít plot, který se jim líbí, ale zničili smysl našeho sousedství. Toto město bylo vytvořeno pro lidi, pro komunitu. Mưj soused, se kterým se skoro neznám, postavil mezi našimi domy vysoký plot. Brala jsem to osobně, $i$ když vím, že 
nemusím. Ale můžu to chápat tak, že nechce vidět moji zahradu a nechce vědèt, kdy jsem doma, aby mě pozval na čaj. Ale to může udělat jen nováček, člověk, který nezná dědictví tohoto mista. Ted'je to tu prostě jiné." (Mari 3, 15. 9. 2018)

Pro Mari se fyzická entita plotu stala symbolem odmítnutí, symbolem nesympatie a nedůvěry. Podle slov Mari ovlivňují fyzické změny prostoru tohoto charakteru i smysl pro komunitu a sousedství. Ne všichni ovšem vnímají tyto prostorové prvky jako vyjádření nedůvěry. Někteř́ informátoři je z hlediska bezpečnosti respektují, připouštějí ovšem jejich neestetičnost a narušování vizuální celistvosti města.

Jinou zkušenost s prostorovými změnami v zahradním městě popsala Anita. Sousedsky nepř́ivětivý charakter ulice Las Tipas se promítl do její každodenní rutiny a ovlivnil tak př́mo Anitin tělesně prožívaný a produkovaný prostor. Procházky po oblíbených cestách, cvičení jógy v parku, jízda na kole v bezprostředním okolí domova se stane součástí každodenní rutiny, skrze kterou se formuje vztah k místu. Výpověd' Anity ilustruje oslabení každodenní rutiny. Procházka, skrze kterou místo prožívá a zakouší, může být vnímána jako tělesně prožívaný i produkovaný rituál, skrze který každodenně upevňuje svůj vztah k místu (Low 2017: 95). Narušení takového rituálu může vyústit $\mathrm{v}$ pocit odcizení a ohrozit přináležení $\mathrm{k}$ místu.

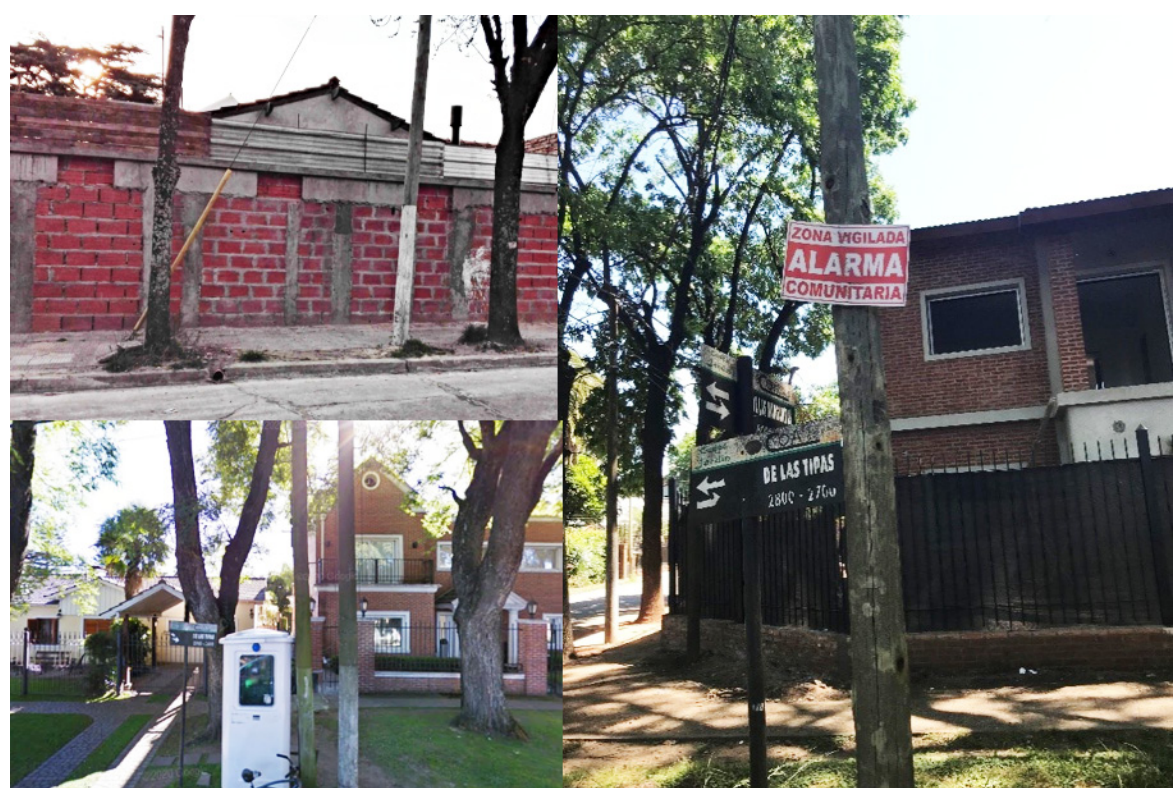

Obr. 4 Materiální symboly nedůvěry v ulici Las Tipas. Foto: autorka, 2018. 
„Každý den chodím na procházky se suým psem. Už je to mnoho let. fe to rutina. Vycházím z Plaza Almirante, kde bydlím, a jdu po okraji města smèrem k Plaza de los Aviadores, kde si nakoupím nebo si jen prohližím výlohy. Vždy tam někoho potkám a zdržím se. Chodívala jsem tam skrze ulici De las Tipas. Tu trasu jsem mèla tak zažitou, že jsem nepremýšlela, kam zahnout a kde jsem, prostèjsem šla. Ted'tam nechodím, protože to není hezké místo na procházení. Jako bych to chtěla proběhnout. Stejnè do ulice často automaticky ze zvyku zahnu, ale pak se vrátím. Necítíme se tam vítáni. "(Anita 1, 8. 11. 2018)

Výše zmíněné výpovědi mých informátorů reagují na prostorové změny zahradního města, které se promítají do sociálního prostoru, zejména do sousedských vztahů, ale i do osobního tělesně prožívaného a produkovaného prostoru jedince. U některých respondentů vyvolávají tyto změny reakce ve formě sentimentálního vzpomínání na „dobu před změnou“, u dalších reakci ve formě aktivního protestu. Právě protest byl př́tomen ve výpovědích Facua, Guilleho, Ruth i Mari. Společně s dalšími rezidenty zahradního města Palomar a v čele s profesorem architektury Hernánem Jagemannem se z nich stali „bojovníci za zachování a obnovu zahradního města Lomas del Palomar“, jak je Ruth nazvala. Častěji objevující se prostorové změny v nich vyvolávaly obavu nad ztrátou místa svého domova, tak jak ho znají.

„Všichni chceme žít v lepším, v pohodlnějším a v bezpečnějším. Nám jde ale o trochu víc. Neznám podobné místo tomu našemu, my nezachraňujeme jen naše domory, my zachraňujeme ten kousek zdravé země. [...] Můžeme si jen stěžovat a potom plakat, můžeme být i bojovníci za zachování a obnovení našeho města." (Ruth 3, 4. 10. 2018)

Při jednom z našich rozhovorů mě Mari pozvala na sousedskou oslavu v rámci Dne urbanismu, který se konal před Muzeem La Montaña 3. prosince 2018. Pořádala ho Mari společně se svou sestrou, s profesorem architektury Hernánem a s pomocí několika aktivních rezidentů, kterým nebyly lhostejné necitelné zásahy do prostoru zahradního města. Hernán se již několik let snažil o to, aby byla uznána architektonická a urbanistická hodnota zahradního města Lomas del Palomar a aby se zamezilo stále intenzivnějším necitlivým zásahům či demolicím v prostoru (zejména přestavbě komerčních budov, která nedodržovala výškové limity okolní zástavby a její architektonickou jednotnost, ale i přestavbě některých soukromých rezidenčních domů). Cílem této akce bylo pozvat sousedy, odborníky 
a městské úředníky a opět s nimi hovořit o jedinečnosti tohoto místa. Tato událost byla důležitým mezníkem mého výzkumu. Nejen že jsem se propojila s mými informátory, kteří se zajímali o to, proč se já zajímám o místo jejich domova, ale i proto, že jsem si uvědomila, jaký význam rezidenti zahradního města místu a podobě svých domovů přikládají. Nebyla to pouze iniciativa Hernána jako architekta ani Mari a její sestry jako aktivních členek komunity, zájem o místo a o zachování jeho kvalit byl pro rezidenty velmi důležitý. Zjistila jsem, že svůj domov vnímají ve vší celistvosti města, že si uvědomují jeho kvality, a i když je nedokážou odborně pojmenovat, mají k místu svého domova intenzivní emocionální vztah - a to nejen proto, že je to zkrátka domov, jedno z nejintimnějších míst člověka, ale i proto, jak jejich domov-město vypadá. Sousedské slavnosti se zúčastnilo několik desítek místních obyvatel. Poslouchali přednášky, prohlíželi si historické fotografie, a hlavně diskutovali o minulosti a budoucnosti zahradního města. Vyjadřovali své obavy, náměty na to, jak předejít neblahým důsledkům, vzpomínali a také se seznamovali, což naznačovalo, že se nejedná o stálou, ale o rozšiřující se sousedskou komunitu, které není lhostejná budoucnost města. Setkání se neúčastnil nikdo z těch, kteří by obhajovali prostorové změny v zahradním městě, i když pozvánky byly rozesílány co největšímu počtu obyvatel.

\section{Diskuse}

Proces sociální produkce a konstrukce prostoru je reciprocitní, to znamená, že způsob produkce ovlivňuje chování aktérů v prostoru, a zároveň jednání a chování aktérů v prostoru a konstruované významy, které mu přikládají, zpětně působí na materialitu místa (Low 2017).

Dle mého pozorování a výpovědí mých informátorů se prostorové změny promítají do sociálního prostoru zahradního města. Významy, které informátoři místu přikládali, byly často explicitně popisovány v souvislosti s fyzickou podobou zahradního města. Ilustrativním př́kladem prostorových změn, které vnímají jako sousedsky nepřátelské, je postupná transformace ulice De las Tipas. Materiální prvky, jako jsou těžkopádné a vysoké betonové ploty, ostnaté dráty, bezpečnostní kamery, cedule, které upozorňují na zákaz fotografování, spolu s fyzicky př́tomnými př́slušníky soukromé bezpečnostní agentury, se staly symbolem odmítnutí, nesympatie a nedůvěry (viz Gibas 2010) a narušením prostorovosti kultury zahradního města Lomas del Palomar. Materiální fragmentace může mít mnoho důvodů. Může symbolizovat ekonomické, sociální, kulturní nebo rasové postavení, zároveň může být čistě estetickou preferencí majitelů. $V$ př́padě zahradního města Lomas del Palomar ovšem tyto 
změny pro moje informátory znamenají zpochybnění původního významu místa - společenské, sociální, kulturní a rasové svobody podporované otevřenými a sdílenými prostory. Postupná přeměna zahradního města vyvolává v některých rezidentech obavu z nezachování místní identity, která odkazovala na rovnost, sousedství a komunitu. Ohroženo bylo (a je) i prožívání prostoru skrze tělesnou praktiku, jako je chůze, jízda na kole a další, které hrají důležitou roli v procesu formování vztahu mezi jedincem a zakoušeným místem. Zkušenost, znalost a samotné utváření místa prostřednictvím těla, které může postupem času přejít v rituál, jehož praktikování v jedinci vyvolá pocit splynutí s místem a pocit přináležení (Low 2017: 108), bylo narušeno. Castells (1996) argumentuje, že narušení teritoriálně definovaných lokalit může vést k oslabení kulturních identit. Ochrana původní identity a historických kořenů, sdílení kolektivní paměti, zachování symbolických míst bez ohledu na současné ekonomické proudy a mocenské vztahy, je jedinou možnou prevencí.

Jedním z aspektů prostorovosti kultury je schopnost uživatelů místa vyjadřovat jejich osobní pocity, preference, názory jako třeba společenský nesouhlas, at' už symbolicky, v podobě rituálu, nebo v podobě společenské aktivity či protestu. Na základě těchto aspektů lze odhalovat významy, které jedinec místu přikládá a na základě kterých utváří své přináležení $\mathrm{k}$ místu. Tyto významy jsem rozdělila do dvou kategorií - reaktioní a proaktioní. Reaktivní významy odkazovaly na přináležení k místu a na znalost místa. Byly hůře identifikovatelné, skryté, přítomny v nejrůznějších historkách, ve vzpomínkách. Sentiment z historicky přátelských sousedských vztahů se proměňoval v pocit strachu z jejich ztráty, který je umocňován př́tomností prvků, jako jsou mřriže, vysoké železné ploty, kamery. Fyzická entita plotu se stala pro některé symbolem odmítnutí, symbolem nesympatie a nedůvěry, pro jiné neestetickou volbou, která narušuje kompaktnost města. Reaktivní významy, které rezidenti místu přikládali na základě změn prostorovosti kultury jejich domovů, se tak staly symbolickým bojem za kulturní reprezentaci prostoru. Druhá, proaktivní kategorie zahrnuje významy, které rezidenti místu přikládají v souvislosti s jeho ochranou. Tyto významy představovaly veřejné projevení nesouhlasu, aktivismus, byly také zhmotněny během rituálních komunitních setkání, která připomínala historii místa a jeho původní charakter. Proaktivní významy byly aktivně produkovány např́klad na sousedské slavnosti v rámci oslav Dne urbanismu, ale i mnohem dříve, ve chvíli, kdy se obava jedince zhmotnila v sousedský protest. Narušení prostorovosti kultury argentinského zahradního města Lomas del Palomar, která byla sociálně produkována fyzickou podobou s nízkopodlažními domky se zahradou, zelenými parky a ulicemi lemo- 
vanými vzrostlými stromy, spolu s ohrožením lidského měřítka města, které podporuje sousedské vztahy, místní soběstačnost a komunitu, jež byly sociálně konstruovány, vyústilo tedy v aktivitu a protest, což může v konečném důsledku posílit vztah $\mathrm{k}$ místu, rekonceptualizovat prostorovost kultury a zabránit tak krizi sousedství.

Významy a symboly, které jsou součástí naší každodennosti, se postupně vpisují do samotného prostoru a stávají se jeho součástí. Proto je ulice De las Tipas pro rezidenty zahradního města symbolem mocenských vztahů, symbolem nerovnosti a producentem konfliktu (Richardson 1982; Rodman 1992). Vrátím se k mé procházce v ulici De las Tipas. Prostor kolem sebe jsem nehodnotila jen vizuálně - tělesně jsem ho prožívala. Skrze pocit, představu a následnou vzpomínku na svou procházku jsem prostor konstruovala pomocí významu, který jsem mu připsala. Vizuálně zřetelné symboly konfliktu se nakonec zhmotnily sociální interakcí s pracovníkem ochranky. Zatím se sice jedná o jednu ulici a o několik nahodilých př́ípadů ve městě. Za rok to už může být jinak. Za rok se $\mathrm{z}$ jedné ulice zahradního města může stát gated community.

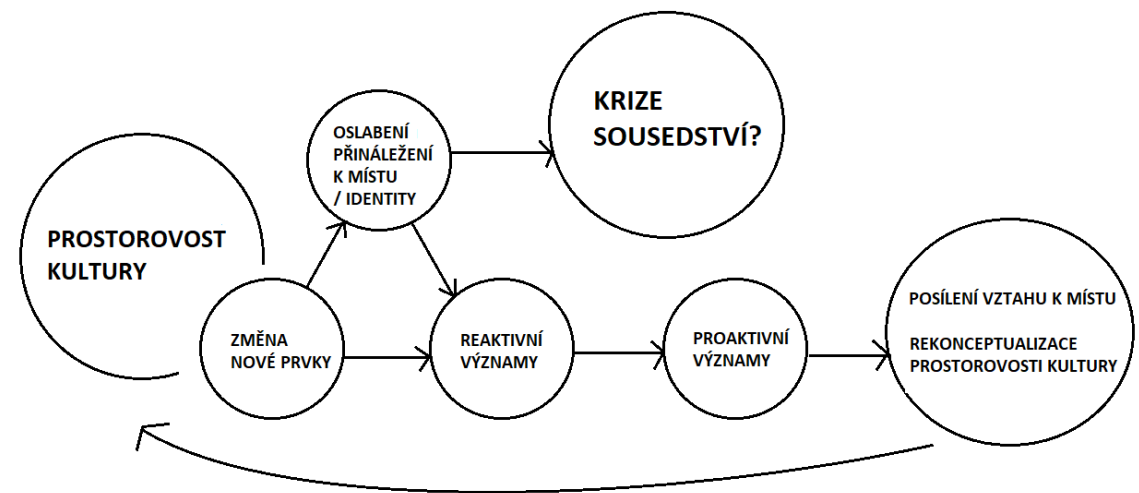

Infografika: Schéma narušení prostorovosti kultury.

\section{Závěr}

Co se stane s prostorovostí kultury teritoriálně definovaného místa, vstoupí-li do něj nové sociálně-prostorové prvky, jako je diskontinuita, nerovnost či bariéra nerespektující jeho původní charakter? Cílem této etnografické studie bylo jednak zjistit, jak se materiální změny prostoru 
města promítají do jeho sociálního prostoru, jak rezidenti skrze tyto změny místo svého domova prožívají a jaké významy mu přikládají. Dále pak rozpracovat koncept narušení prostorovosti kultury a tím přispět k pojetí prostorovosti kultury Sethy Low (2017) a rozšśřit tak studia o městě a domově.

Studie vycházela z pojetí prostorovosti kultury Sethy Low (2017), jejímž jádrem je vzájemný proces, který spojuje sociální, ekonomické, ideologické a technologické aspekty tvorby hmotného prostředí s fenomenologickými a symbolickými zkušenostmi zprostředkovanými sociálními procesy, jako jsou výměna, konflikty a kontrola. Zvláštní důraz byl kladen na tělesné prožívání a produkování prostoru (embodied space) a na způsob, kterým jedinec přikládá místu významy a formuje tak své přináležení k místu (Manzo 2020). Studie ilustrovala, že přináležení k místu je neustále vyjednáváno skrze osobní či kolektivní prožívání a produkování každodenních rutin, praxí a rituálů, skrze sdílení přikládaných významů s ostatními členy komunity, zároveň i skrze narušení prostorovosti kultury. Přičemž narušení nemusí nutně vést $\mathrm{k}$ oslabení přináležení k místu a ke krizi sousedství, nýbrž k rekonceptualizaci prostorovosti kultury. Narušení v př́padě zahradního města Lomas del Palomar funguje jako katalyzátor produkce nových významů - reaktivních a proaktivních, jako je aktivismus, péče a starost o místo, které v konečném důsledku opět posilují přináležení k místu a k sousedství. Skrze narušení si v určitých př́padech jedinec uvědomí a určí, kým v místě svého domova je, jak místu rozumí a co pro něj znamená, čímž opět konstruuje samotné prináležení k místu.

Prostorovost kultury považuji za dynamický proces utvářející se skrze fyzickou materialitu domu a významovou rovinu domova, který je prostřednictvím jedince nebo skupiny neustále vyjednáván, konstruován, narušován či rekonceptualizován. Domnívám se, že ke kompletnímu obrazu narušení prostorovosti kultury zahradního města Lomas del Palomar by bylo zapotřebí do výzkumu zahrnout i hlas nově přistěhovalých rezidentů, což se v rámci této studie bohužel nepodařilo. Jak jsem ovšem ukázala, narušení prostorovosti kultury není jen užitečným konceptuálním rámcem, ale také nástrojem, jenž napomáhá odhalování každodenností, které posilují přináležení $\mathrm{k}$ místu, zároveň nepřehlíží sociální nespravedlnosti či formy vyloučení, které ji oslabují. Tak, jak tomu bylo v př́padě této studie, narušení prostorovosti kultury může být podnětem pro sousedský aktivismus a může podpořit ochranu místa, zamezit nechtěným zásahům, nebo alespoň nastartovat diskusi. 


\section{Literatura:}

Almandoz, Arturo. 2004. The garden city in early twentieth-century Latin America. Urban History 31, 3: 437-452.

Altman, Irwin - Low, Setha. 1992. Place attachment. New York: Plenum Press.

Berger, Peter - Luckmann, Thomas. 1967. The Social Construction of Reality. The Penguin Press.

Brown, Barbara - Perkins, Douglas. 1992. Disruptions in place attachment. In: Altman, Irwin - Low, Setha (eds.): Place attachment. Springer: Boston: 279-304.

Castells, Manuel. 1996. The Rise of the Network Society. Malden, MA: Blackwell.

Devereux, Michael. 2015. International interpretations of the garden city ideal: Lessons for placemaking. Urban Design 134: 32-34.

F.I.N.C.A Magazine. San Martin, Buenos Aires. 1947, č. 55, 73, 98. Biblioteca Popular Ciudad Jardín.

F.I.N.C.A. Magazine. San Martin, Buenos Aires. 1949, č. 111, 118. Biblioteca Popular Ciudad Jardín.

Gallanter, Eden. 2012. Ciudad Jardín Lomas del Palomar: deriving ecocity design lessons from a garden city. Planning Perspectives 27, 2: 297-30.

Galčanová, Lucie et al. 2014. Domov lidí, kteř́ žijí sami. Masarykova Univerzita.

Gibas, Petr. 2010. Ballet amidst fences: Placelessness and place-attachment in one prague suburb. Slovenský národopis 58, 5: 584-597.

Gibas, Petr. 2017. Domov jako konceptuální rámec, téma i výzkumný terén: vývoj i současná podoba studií domova. Sociologický časopis 53, 2: 241-268. https://doi.org/10.13060/00380288.2017.53.2.315

Harvey, David. 1973. Social Justice and the City. Baltimore: John Hopkins Press.

Hirsch, Eric. 1995. Landscape: Between Place and Space. In: Hirsch, Eric - O’Hanlon, Michael (eds.): The Anthropology of Landscape:

Perspectives on Place and Space. Oxford: Clarendon Press: 1-30.

Horská, Pavla - Maur, Eduard - Musil, Jiř́. 2002. Zrod velkoměsta: urbanizace českých zemí a Evropa. Praha: Paseka.

Howard, Ebenezer. 1946. Garden Cities Of Tomorrow. London: Faber and Faber.

Jagemann, Hernán. 2016. Ciudad Jardín: la forma pública del espacio privado, la forma privada del espacio público. UBA, Fadu.

Lefebvre, Henri. 1991. The Production of Space. Cambridge - New York: Blackwell. 
Low, Setha. 2000. Cultura in the modern city: the microgeographies of gender, class, and generation in the costa rican plaza. Horizontes Antropológicos 6, 13: 31-64.

Low, Setha. 2003. The anthropology of space and place. Oxford: Blackwell.

Low, Setha. 2017. Spatializing Culture. The Ethnography of Space and Place. London: Taylor \& Francis.

Mácha, Přemysl. 2010. Krajina antropologie a antropologie krajiny. Český lid 97, 3: 225-245.

Manzo, Lynne - Devine-Wright, Patrick (eds.). 2020. Place attachment: Advances in theory, methods and applications. London: Routledge. https://doi.org/10.4324/9780429274442

Moura, Cristina Patriota. 2003. Gates and open spaces: new arrangements in Brazil. In: Conference Gated Communities: Building Social Divisions or Safer Communities? Department of Urban Studies, University of Glasgow.

Prohanski, Harold M. 1978. The city and self identity. Environment and Behaviour 10, 2: 147-169.

Richardson, Miles 1982. Being-in-the-Market versus Being-in-the-Plaza: Material Culture and the Construction of Social Reality in Spanish America. American Ethnologist 9: 421-436.

Rodman, Margaret C. 1992. Empowering Place: Multilocality and Multivocality. American Anthropologist 94, 640-656.

Sargent, Charles. 1974. The Spatial Evolution of Greater Buenos Aires, Argentina, 1870-1930. Tempe: Center for Latin American Studies, Arizona State University.

Taylor, Charles. 1995. Philosophical arguments. Cambridge: Harvard University Press.

Vacková, Barbora. 2010. Prostor, moc a utopie: ideální město a jeho společnost. Brno: Masarykova univerzita, Mezinárodní politologický ústav.

Zeyen, Erich. 1933-1948. Así La Levantamos Ediciones La Montaña. Biblioteca Popular Ciudad Jardín. 